\title{
HR-MAS NMR Allied to Chemometric on Hancornia speciosa Varieties Differentiation
}

\author{
Igor S. Flores, ${ }^{a}$ Andressa K. Silva, ${ }^{b}$ Leonnardo C. Furquim, ${ }^{c}$ Carlos F. S. Castro, ${ }^{d}$ \\ Lazaro J. Chaves, ${ }^{e}$ Rosane G. Collevattif and Luciano M. Lião ${ }^{*, b}$ \\ ${ }^{a}$ Instituto Federal de Goiás, R. São Bartolomeu, s/n, Vila Esperança, \\ 72811-580 Luziânia-GO, Brazil \\ ${ }^{b}$ Instituto de Química, Universidade Federal de Goiás, Av. Esperança, s/n, \\ Campus Samambaia, 74690-900 Goiânia-GO, Brazil \\ 'Faculdade Objetivo, Rua 12 de Outubro, Quadra 64, Lote 02, Jardim Adriana, \\ 75906-577 Rio Verde-GO, Brazil \\ dInstituto Federal de Educação, Ciência e Tecnologia Goiano, Rod. Sul Goiana, km 01, \\ Zona Rural, CP 66, 75901-970 Rio Verde-GO, Brazil \\ ${ }^{e}$ Escola de Agronomia and Instituto de Ciências Biológicas, Universidade Federal de Goiás, \\ Campus Samambaia, CP 131, 74690-900 Goiânia-GO, Brazil
}

\begin{abstract}
This work describes the potential of chemometric analyses applied to ${ }^{1} \mathrm{H}$ high-resolution magic angle spinning nuclear magnetic resonance ( ${ }^{1} \mathrm{H}$ HR-MAS NMR) data for the chemotaxonomic investigation of Hancornia speciosa (Apocynaceae) varieties. This plant, popularly known as mangaba, has a complex morphological differentiation and thus chemical analyses can be used for their taxonomic classification. In comparison to traditional techniques, ${ }^{1} \mathrm{H}$ HR-MAS NMR allied with chemometrics provided a simple and low cost method for chemotaxonomy. Leaves of four varieties of $H$. speciosa from a common garden experiment was studied and demonstrated that $H$. speciosa var. speciosa differs from others due to its specific metabolic profile, and var. pubescens was discriminated based on its high phenolic compound content. The distinction between the latter variety and gardineri is important once it allows for the selection of samples with greater commercial value, once they produce the largest and heaviest fruits.
\end{abstract}

Keywords: Apocynaceae, Hancornia speciosa, chemotaxonomy, HR-MAS NMR, chemometrics/statistics

\section{Introduction}

The species Hancornia speciosa Gomes (Apocynaceae), popularly known as mangabeira or mangaba, is widely distributed throughout Brazil. ${ }^{1}$ Although it is important in the production of latex, its fruit has also been explored for other uses, especially by the pulp, juice and ice cream industries. ${ }^{2,3}$ The species presents variation in morphological leaf traits according to geographical origin and varieties, ${ }^{4}$ although with sympatric varieties and individuals with intermediate phenotypes. ${ }^{5} \mathrm{H}$. speciosa var. speciosa (Gomes) has small leaves with long petiole and occurs from the Northeast towards the Middle-West

*e-mail: lucianoliao@ufg.br and North Brazil. On the other hand, var. maximilliani (A. DC.) occurs in Southeast Brazil and also has small leaves with long petiole. The var. lundii (A. DC.) also occurs in Southeast Brazil and has medium leaves and short petiole. H. speciosa var. cuyabensis (Malme) occurs in Middle-West Brazil and has medium leaves and short petiole. The varieties gardneri (A. DC. Muell. Arg.) and pubescens (Nees \& Martius) Muell. Arg. occur in MiddleWest Brazil and have large leaves and short petiole, although the last one has pubescent leaves. The species also has great variation among populations in fruit size, color and production. ${ }^{6}$ The sympatric distribution of varieties, the high morphological variation among populations and the individuals with intermediate phenotypes hinder the identification of varieties. 
In folk medicine, the bark of $H$. speciosa is used in an infusion form for the treatment of gastric ulcers, hypertension, inflammatory diseases and stomach disturbances. ${ }^{7,8}$ In addition, the species is also used to control diabetes, dermatitis, hepatic and pulmonary disease, tuberculosis and weight loss. ${ }^{9-12}$ Phytochemical analyses describes cyclic polyol bornesitol and phenolic acids, such as ferulic, gallic, $p$-coumaric, protocatechuic, vanillic, quinic and chlorogenic acids; flavonoids, such as rutin, kaempferol di- and triglycoside; triterpenes and steroids; as well as a homologous series of B-type proanthocyanidins and their respective C-glycosylated derivatives, with a degree of polymerization ranging from 1 to 6 units of interlinked catechins. ${ }^{12-16}$ However, to the best of our knowledge no chemical profile study has yet been performed comparing the different varieties of $H$. speciosa.

The metabolic profile of plants is usually characterized by techniques that separate the chemical compounds, often involving time and chemical consuming and laborious sample pre-treatment. In this context, the present work aims on the application of ${ }^{1} \mathrm{H}$ high-resolution magic angle spinning nuclear magnetic resonance (HR-MAS NMR) associated with chemometric analysis to provide a fast and secure way to evaluate the chemotaxonomy of H. speciosa varieties. In this way, four varieties of $H$. speciosa from a germplasm collection: var. speciosa, cuyabensis, gardneri and pubescens, were analyzed. HR-MAS is generally employed as a fast tool to detect some of the major metabolites of a heterogeneous matrix (i.e., gel like systems), swollen in a specific solvent in order to improve molecular mobility. Importantly, no extraction process is necessary, thereby minimizing chemical reactions with solvent, which can occur in traditional extraction methods. ${ }^{17-21}$

\section{Experimental}

\section{Plant materials}

Fruits of $H$. speciosa were collected over a period of two months in the Cerrado biome, covering the states of Goiás, Tocantins, Mato Grosso, Mato Grosso do Sul, Minas Gerais, and Bahia. The prime trees, found in their respective places of occurrence, were selected based on their phytosanitary characteristics and the availability of fruits for collection. The collected fruits were then used to produce a germplasm collection at Federal University of Goiás, Goiânia City, Brazil (16³5'12”S, 49²1'14”W, elevation $730 \mathrm{~m}$ ), to avoid environmental influence in metabolic profiling.
The collection was planted in 2005 in a completely randomized block design and consists of openpollinated progenies from 109 plant matrices sampled in 32 populations. ${ }^{5}$ The collection has now 274 adult individuals regarding four varieties of $H$. speciosa: var. pubescens (65 individuals), var. gardineri (159), var. speciosa (21), and var. cuyabensis (29). Then, leaf samples obtained from 70 adult individuals regarding the four varieties (Table 1) were submitted to NMR analysis.

NMR analyses

All NMR spectra were acquired on a Bruker Avance III 500 spectrometer operating at 11.75 Tesla, observing ${ }^{1} \mathrm{H}$ at $500.13 \mathrm{MHz}$, equipped with a $4 \mathrm{~mm}$ four channel $\left({ }^{1} \mathrm{H}\right.$, ${ }^{2} \mathrm{H},{ }^{13} \mathrm{C}$ and ${ }^{31} \mathrm{P}$ ) HR-MAS probe. The H. speciosa leaves, previously dried for three days at room temperature, were powdered without the addition of liquid nitrogen, avoiding water condensation after grinding, and sieved through a $1 \mathrm{~mm}$ mesh. The powdered leaves $(12 \mathrm{mg})$ were then transferred into a $50 \mu \mathrm{L}$ HR-MAS zirconium rotor followed by $40 \mu \mathrm{L}$ of $\mathrm{CD}_{3} \mathrm{OD}(0.05 \% \mathrm{v} / \mathrm{v}$ tetramethylsilane (TMS)) and it was waited one hour for sample swelling. Samples were spun at $5 \mathrm{kHz}$ at magic angle $\left(54.74^{\circ}\right.$ ) and the spectra were acquired at $25{ }^{\circ} \mathrm{C}$ in triplicate, using Carr-PurcellMeiboom-Gill (CPMG) water presaturation (cpmgpr1d Bruker) pulse sequence ([RD(CW)-90 $\left.\left.{ }_{\mathrm{x}}-\left(\tau-180^{\circ}-\tau\right)_{\mathrm{n}}-\mathrm{FID}\right]\right)$ with 128 cycles. During all RD (recycle delay) the water frequency was selectively irradiated. The delay between 180 -degree pulses $(\tau)$ and number of cycles $(n)$ were optimized varying in: 1.0, 1.5 and $2.0 \mathrm{~ms}$ for $\tau$, and 128 , 256 and 512 cycles for $n$. Receiver gain was adjusted automatically and shimming manually before each acquisition. Typically, 128 free induction decays (FID) were collected into $117 \mathrm{~K}$ data points distributed in a $10,000 \mathrm{~Hz}$ spectral width, with a relaxation delay of $3 \mathrm{~s}$ and an acquisition time of $6.0 \mathrm{~s}$. The standard inversionrecovery approach was used for measuring longitudinal relaxation time $\left(\mathrm{T}_{1}\right)$ and the recycle delay was set up to 5 times the longest $T_{1}$ determined. Spectra were processed by application of an exponential multiplication of FID by a factor of $0.4 \mathrm{~Hz}$ followed by Fourier transform, without zero-filling.

\section{Chemometric analysis}

The ${ }^{1} \mathrm{HNMR}$ data were submitted to chemometric analysis using OCTAVE software (version 4.2).22 Savitzky-Golay smoothing filters were applied with a window width of 15 points for the adequate treatment of noise, especially in regions of signals with a low signal-to-noise ratio. ${ }^{23}$ Data 
Table 1. Samples varieties from Hancornia speciosa used in this investigation

\begin{tabular}{|c|c|c|c|c|c|}
\hline Leaf sample & H. speciosa variety & Matrix origin $^{\mathrm{a}}$ & Leaf sample & H. speciosa variety & Matrix origin $^{\mathrm{a}}$ \\
\hline 1 & gardineri & Silvânia-GO & $33-35$ & gardineri & Coxim-MS \\
\hline $2-3$ & gardineri & Pirenópolis-GO & 36 & gardineri & Coxim-MS \\
\hline 4 & gardineri & Silvânia-GO & 37 & gardineri & Porangatu-GO \\
\hline 5 & gardineri & Sonora-MS & 38 & gardineri & Coxim-MS \\
\hline 6 & gardineri & Silvânia-GO & 39 & gardineri & Porangatu-GO \\
\hline 7 & gardineri & Pirenópolis-GO & 40 & gardineri & Sonora-MS \\
\hline $8-9$ & gardineri & Sonora-MS & $41-44$ & cuyabensis & Chapada dos Guimarães-MT \\
\hline 10 & gardineri & Silvânia-GO & $45-46$ & cuyabensis & Rondonópolis-MT \\
\hline 11 & gardineri & Pirenópolis-GO & 47 & cuyabensis & Chapada dos Guimarães-MT \\
\hline 12 & gardineri & Costa Rica-MS & 48 & cuyabensis & Jaciara-MT \\
\hline 13 & gardineri & Sonora-MS & 49 & cuyabensis & Chapada dos Guimarães-MT \\
\hline $14-16$ & gardineri & Pirenópolis-GO & 50 & cuyabensis & Jaciara-MT \\
\hline 17 & gardineri & Sonora-MS & $51-56$ & cuyabensis & Rondonópolis-MT \\
\hline 18 & gardineri & Costa Rica-MS & $57-58$ & cuyabensis & Chapada dos Guimarães-MT \\
\hline $19-20$ & gardineri & Sonora-MS & $59-60$ & pubescens & Barro Alto-GO \\
\hline 21 & speciosa & Jalapão-TO & $61-62$ & pubescens & Campinorte-GO \\
\hline 22 & speciosa & São Desidério-BA & $63-65$ & pubescens & Alexânia-GO \\
\hline $23-27$ & speciosa & Jalapão-TO & 66 & pubescens & Campinorte-GO \\
\hline $28-30$ & speciosa & Japonvar-MG & 67 & pubescens & Barro Alto-GO \\
\hline 31 & gardineri & Coxim-MS & 68 & pubescens & Alexânia-GO \\
\hline 32 & gardineri & Silvânia-GO & $69-70$ & pubescens & Barro Alto-GO \\
\hline
\end{tabular}

${ }^{\mathrm{a} B r a z i l i a n}$ states: Bahia (BA); Goiás (GO); Minas Gerais (MG); Mato Grosso do Sul (MS); Mato Grosso (MT); Tocantins (TO).

normalization was also carried out to minimize discrepancies arising from the homogeneity of the magnetic field. Principal component analysis (PCA) was performed with and without selection of variables, mean-centering and auto-scaling, and evaluated based on similarity according to variety, location and family; regions concerning water suppression, deuterated solvent signal and spectral noise were removed. We also performed hierarchical analysis of clusters (HCA) to visualize the degree of similarity between samples, using the same software as above.

\section{Results and Discussion}

The pulse sequences zgcppr $\left(\left[\mathrm{RD}(\mathrm{CW})-90^{\circ}{ }_{\mathrm{x}}-90^{\circ}{ }_{\mathrm{y}}-90^{\circ}{ }_{-\mathrm{x}}{ }^{-}\right.\right.$ $90^{\circ}{ }_{-\mathrm{y}}$-FID] $)$, cpmgpr1d ([RD $\left.\left.(\mathrm{CW})-90^{\circ}{ }_{\mathrm{x}}-\left(\tau-180^{\circ}{ }_{\mathrm{y}}-\tau\right)_{\mathrm{n}}-\mathrm{FID}\right]\right)$, noesygppr $1 \mathrm{~d}\left(\left[\mathrm{RD}(\mathrm{CW})-90^{\circ}-90^{\circ}-\mathrm{t}_{\mathrm{m}}(\mathrm{CW})-90^{\circ}-\mathrm{FID}\right]\right)$ using spoil gradient, where $t_{\mathrm{m}}$ is the mixing time of $100 \mu \mathrm{s}$ in which the water resonance was also irradiated, were evaluated for suppression of the water hydrogen signal. The more informative spectra (i.e., presented higher signal-to-noise relationship, and lower signal overlapping) were achieved with the aid of cpmgprld pulse sequence. The advantage of this pulse sequence is the suppression of broad signals typical of complex samples, as natural samples in general, generated by macromolecule due to its very fast spin relaxation. Thus, elimination of these signals provides clearer spectra with less distortion at the baseline, making spectra more informative (Figure 1). A similar case in which this pulse sequence was used and good chemotaxonomic analysis results were achieved was reported by Alcantara et al. ${ }^{17}$

Average sample spectra for each $H$. speciosa variety (speciosa, cuyabensis, gardineri and pubescens) were generated and overlapped in an attempt to reveal the differences in the chemical composition (Figure 2a). Analysis of this figure reveals appreciable similarities between the four varieties, with differences observed only for var. speciosa in the regions of aromatic compounds ( $\delta 6.0$ to 9.0 ) and carbohydrates ( $\delta 3.0$ to $5.0)$, as well as a little more pronounced at $\delta 1.6$ and 2.0. Variety speciosa shows reduced signal intensity in these regions, which indicates lower amounts of the respective compounds in this variety than in the other three. Thus, only the regions in which these signals were contained were selected for PCA analysis (Figure 2b). This result demonstrates that visual analysis of average 

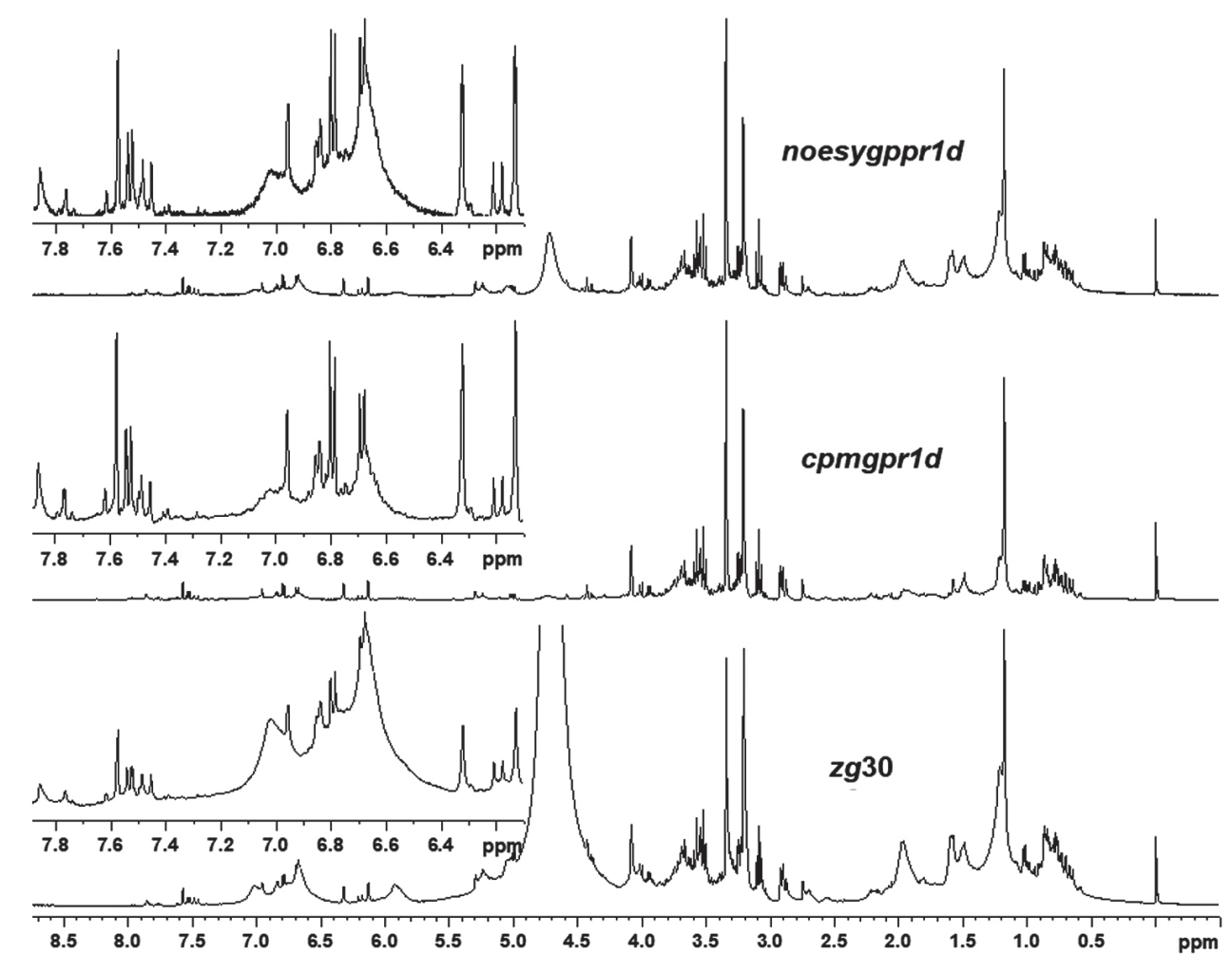

Figure 1. Representative ${ }^{1} \mathrm{H}$ HR-MAS NMR spectra from Hancornia speciosa leaves acquired with different pulse sequences: $\mathrm{zg} 30$ ([RD-30 ${ }^{\circ}$-FID]),

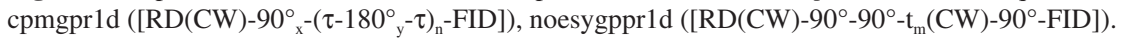

spectra can subsidize the selection of variables for pattern recognition in samples of interest, in this case H. speciosa var. speciosa.

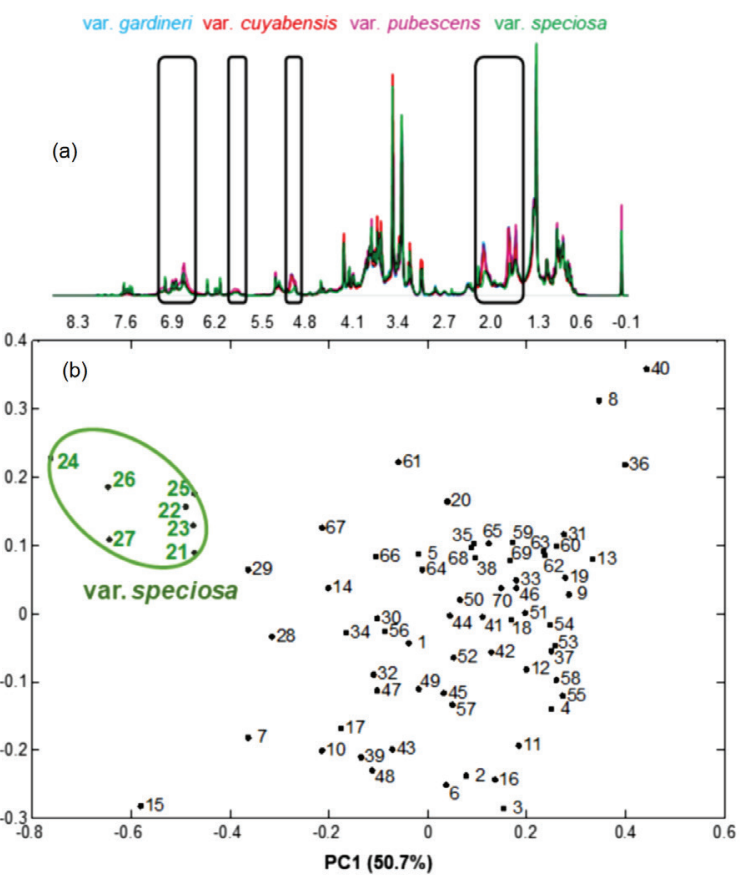

Figure 2. (a) Average ${ }^{1} \mathrm{H}$ HR-MAS NMR spectra of Hancornia speciosa leaves, the highlighted regions were responsible to discriminate each variety on PCA analysis; (b) PCA score plots with selection of variables.
Among the most important components present in H. speciosa are the phenolic compounds, which are responsible for the medicinal properties of this plant. ${ }^{12}$ For this reason, only signals present in the region associated with these compounds were selected to identify the variety of mangaba most reflecting this characteristic. When phenolic region were selected for chemometric analysis, a polarization of samples of $H$. speciosa var. pubescens in relation to the other three varieties under study was observed (Figure 3). Almost all tested individuals of this variety exhibit negative scores for both PCs, particularly when considering the first components, which accounts for over eighty percent of original data variance in this region. This result emphasizes the chemical differentiation of the four mangaba varieties, with $H$. speciosa var. pubescens containing the highest amount of phenolic compounds.

Examination of the PC1 and PC2 loadings of ${ }^{1} \mathrm{H}$ HR-MAS NMR data suggests that this separation occurs due to the signals typical of aromatic compounds. These signals could be assigned to the flavonoid rutin on basis of the doublets at $\delta 7.67(J=2.1 \mathrm{~Hz})$ and $6.90(J=8.5 \mathrm{~Hz})$, and a double doublet at $\delta 7.64(J=8.5$ and $2.1 \mathrm{~Hz}),{ }^{24}$ as well as one-bond and long-range ${ }^{1} \mathrm{H}-{ }^{13} \mathrm{C}$ correlation from heteronuclear single quantum correlation (HSQC) and heteronuclear multiple bond correlation (HMBC) NMR experiments. 


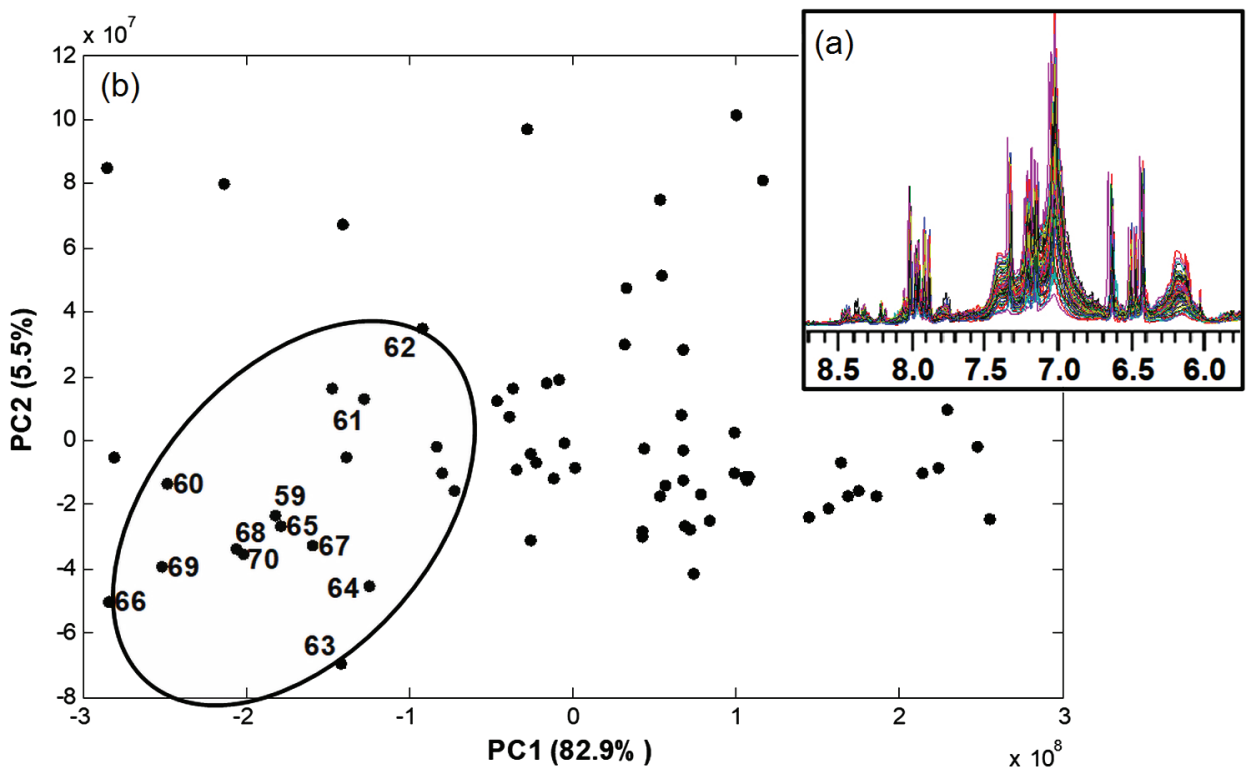

Figure 3. (a) ${ }^{1} \mathrm{H}$ HR-MAS NMR spectra of four varieties of Hancornia speciosa leaves, highlighting the phenolic compounds region; (b) PCA score plots with selection of variables (phenolics) and mean-centered data. The $H$. speciosa var. pubescens samples are highlighted.

No clusters were observed among varieties considering carbohydrates and saturated hydrocarbon signals. However, the carbinolic hydrogen signal at $\delta 3.5$ suggests the presence of $\beta$-sitosterol, as supported by that of olefinic hydrogen at $\delta 5.3$, while the presence of 3- $\beta$ - $O$-acyl lupeol is suggested by the signals at $\delta 1.6$ and $1.7 . .^{25}$ On the other hand, H. speciosa var. speciosa is distinguished by its lower contents of this compound, as can be observed in Figure 2.

Sample separation according to variety was also determined based on all ${ }^{1} \mathrm{H}$ HR-MAS NMR spectral information (i.e., full ${ }^{1} \mathrm{H}$ NMR spectra) (Figure 4). H. speciosa var. pubescens is better discriminated due to chemical differentiation in the phenolic hydrogen region. H. speciosa var. cuyabensis presents certain chemical characteristics similar to those of var. gardineri and var. speciosa, although the latter two varieties are very different from each other.

The two sympatric varieties, $H$. speciosa var. gardineri and var. pubescens, can be discriminated based on their association with positive values of PC2 and negative

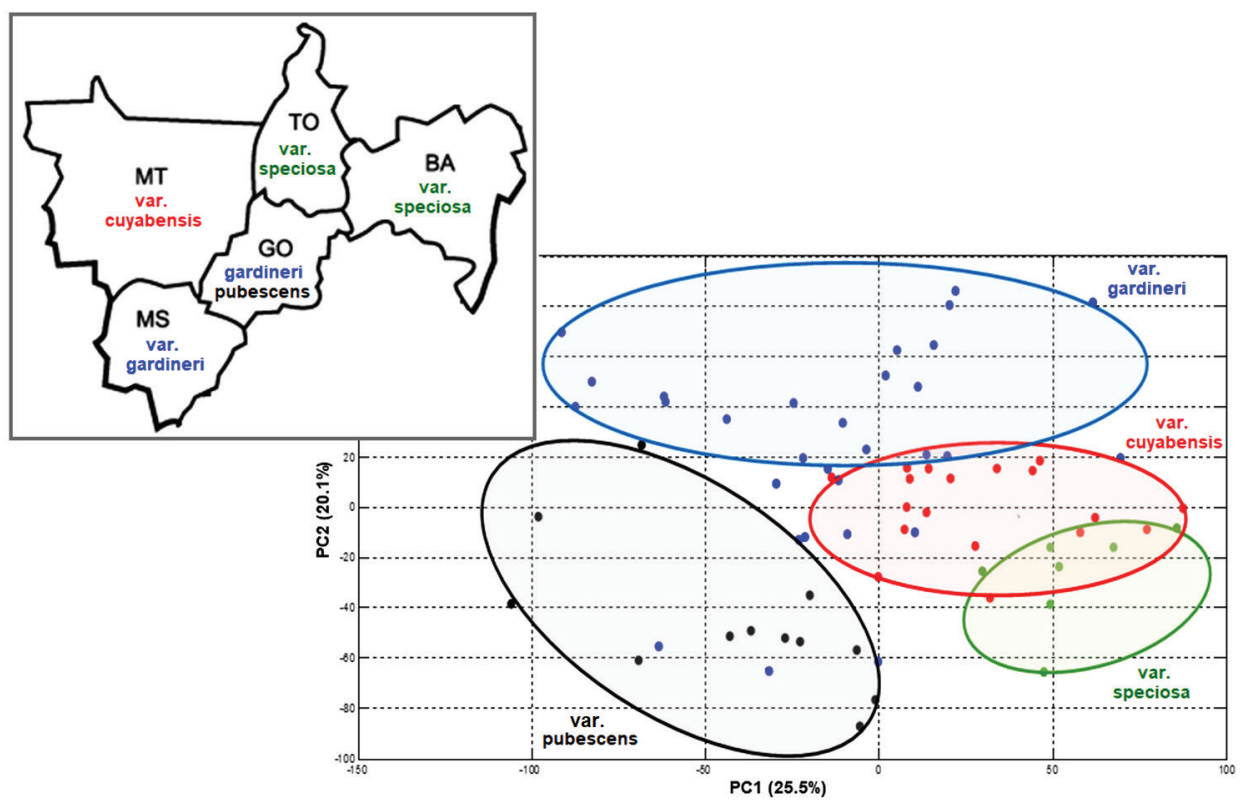

Figure 4. PCA score plot ( $\mathrm{PC} 1$ versus $\mathrm{PC} 2)$ obtained from ${ }^{1} \mathrm{H}$ NMR data for Hancornia speciosa varieties. The map insert shows the geographical origin of plant matrices in the germplasm collection, and the colors represents the different varieties as described in the map. Brazilian states: Bahia (BA); Goiás (GO); Mato Grosso do Sul (MS); Mato Grosso (MT); Tocantins (TO). 
values of PC1, respectively. According to loading plots, while samples of $H$. speciosa var. pubescens are separated from the other varieties mainly due to their higher phenolic compound content, samples of var. gardineri are distinguished by their hydrocarbon and carbohydrate signals. Resonances at $\delta 2.6$ and 2.8, in addition to lower contents of phenolic and carbohydrate compounds, are responsible for the location of the H. speciosa var. speciosa samples at positive PC1 and negative PC2 scores. Finally, the var. cuyabensis samples are located near the origin of the two components.

HCA analyses were then performed using all ${ }^{1} \mathrm{H}$ HR-MAS NMR spectral information, based on previously smoothed and normalized data. PCA data were not employed, with the k-means method used for distance calculation. Taking information for all compound classes into account, the major distances were observed between H. speciosa var. speciosa and var. pubescens (Figure 5). On the other hand, H. speciosa var. cuyabensis and var. gardineri showed to have more similarity.

Although the plants used in this study were sampled in a germplasm collection, grown in a common garden experiment under the same environmental conditions, the analyses showed that the geographic origin of each plant had a direct influence on its chemical composition. The PCA plot showed that collection site had a significant influence on plant chemical profile, with six distinct regions discernible (Figure 6).

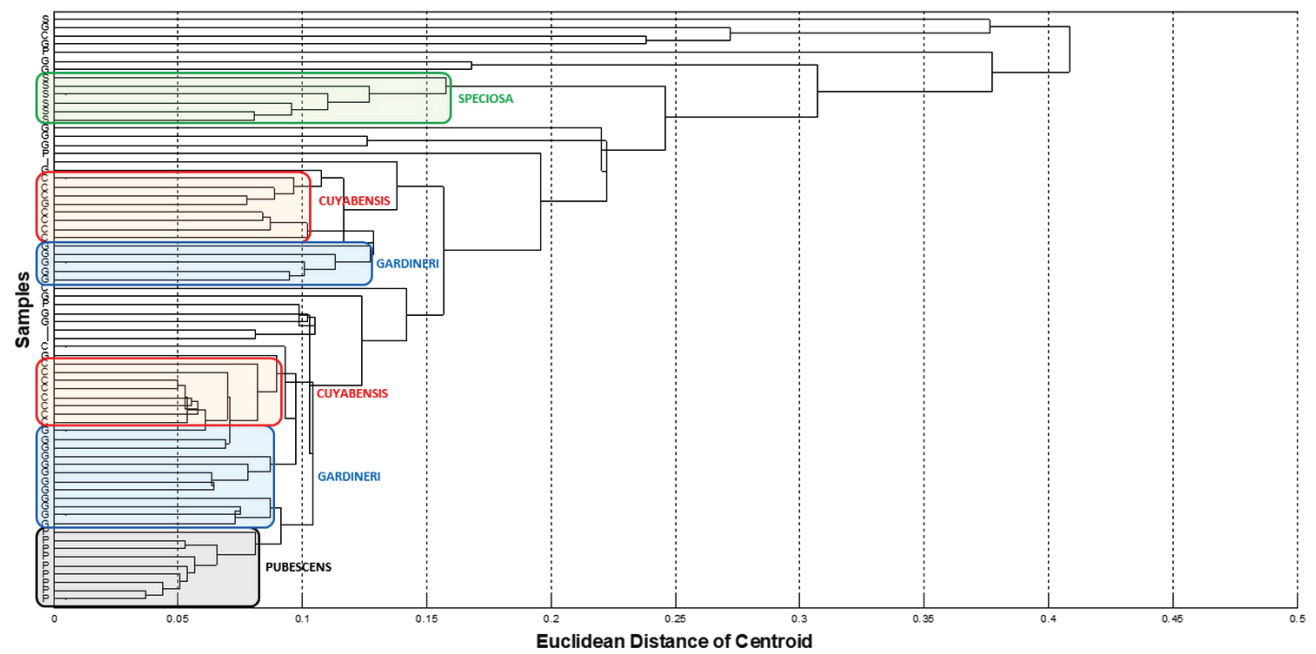

Figure 5. HCA plot obtained from ${ }^{1} \mathrm{H}$ HR-MAS NMR spectral data for Hancornia speciosa varieties (similarity index: 0.377).

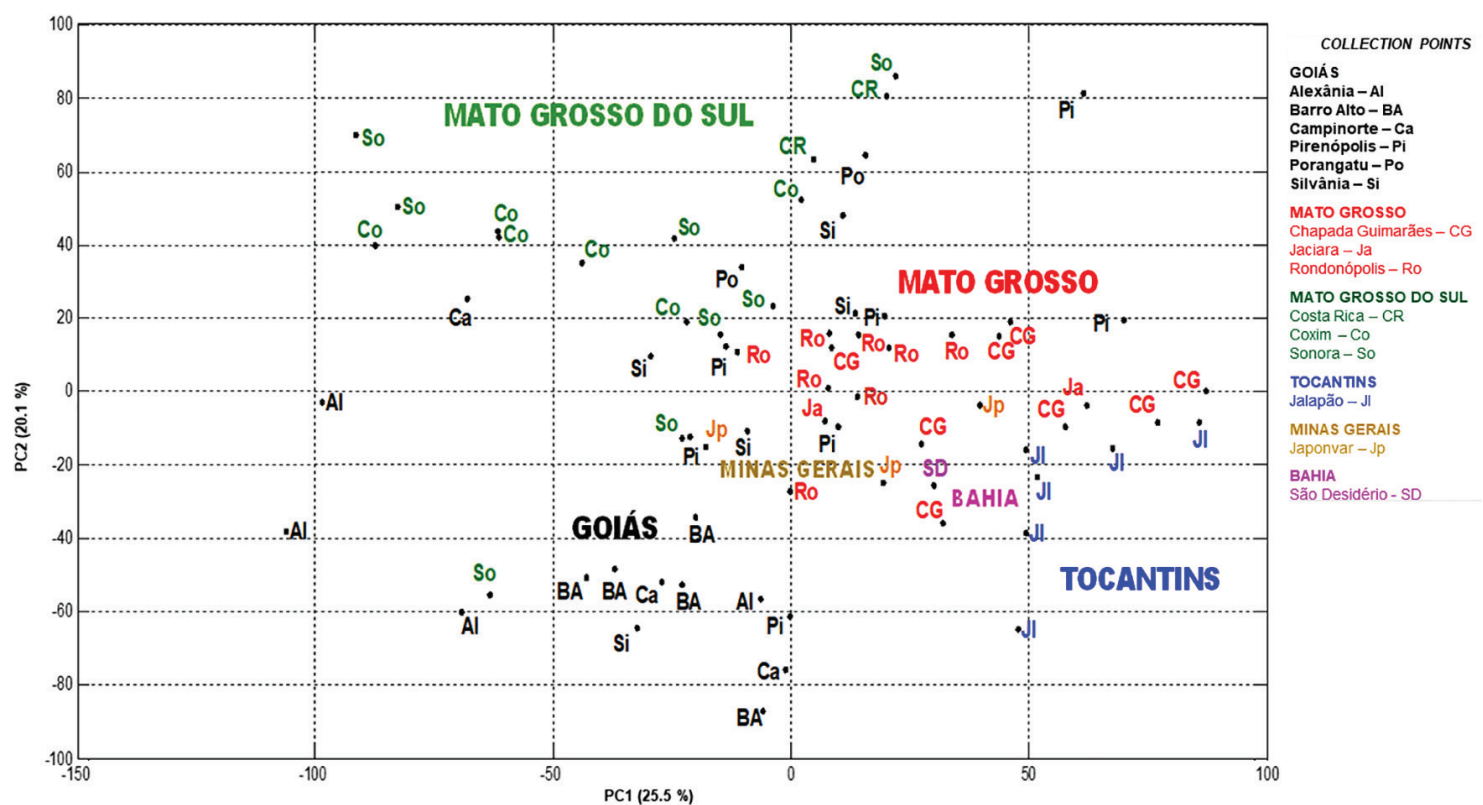

Figure 6. PCA score plot (PC1 versus PC2) obtained from ${ }^{1} \mathrm{H}$ HR-MAS NMR data for Hancornia speciosa varieties. Prime samples were collected in six Brazilian states, as represented by the different colors. 


\section{Conclusions}

This work shows that the chemotaxonomic differentiation of Hancornia speciosa varieties is possible on the basis of chemometric analyses of ${ }^{1} \mathrm{H}$ HR-MAS NMR spectral data. H. speciosa shows high levels of phenotypic variation among populations in leaf and fruit characters which make it difficult to identify individual varieties, thus our study may contribute to the identification of varieties, which is highly important for breeding programs and genetic resources conservation. H. speciosa var. speciosa variety is distinct from the three others under study because it exhibits higher chemical differentiation, while var. pubescens can be identified based on its higher levels of phenolic compounds. Perfect distinction between the latter variety and var. gardineri is important once they are sympatric and it would enable the selection of samples with greater commercial value. Moreover, the results showed the influence of plant origin in plant chemical composition. The difference in chemical composition was not due to environment because it used leaf samples from a common garden experiment, thus all variation might be due to genetic differentiation or maternal effect in varieties.

\section{Acknowledgments}

This work was supported by grants to the research network GENPAC10 (CNPq/MCT/CAPES/FAPEG project No. 564717/2010-0, 563624/2010-8), the network Rede Cerrado PPBio (CNPq project No. 457406/2012-7) and the network Rede Pró-Centro-Oeste (MCTI/CNPq/FNDCT project No. 407181/2013-0). The authors are also grateful to FINEP, FAPEG, CNPq and CAPES for the continuous financial support and scholarships.

\section{References}

1. Lorenzi, H.; Árvores Brasileiras: Manual de Identificação de Plantas Nativas do Brasil, $1^{\text {a }}$ ed.; Plantarum: Nova Odessa, 1992.

2. Soares, F. P.; Paiva, R.; Alvarenga, A. A.; Nogueira, R. C.; Emrich, E. B.; Martinotto, C.; Ciênc. Agrotec. 2007, 31, 1048.

3. da Rosa, M. E. C.; Naves, R. V.; de Oliveira Júnior, J. P.; Pesq. Agropec. Trop. 2005, 35, 65.

4. Monachino, J.; Lilloa 1945, 11, 19.

5. Collevatti, R. G.; Olivatti, A. M.; Telles, M. P. C.; Chaves, L. J.; Tree Genet. Genomes 2016, 12, 74.

6. Ganga, R. M. D.; Ferreira, G. A.; Chaves, L. J.; Naves, R. V.; Nascimento, J. L.; Rev. Bras. Frutic. 2010, 32, 101.
7. Almeida, S. P.; Proença, C. E. B.; Sano, S. M.; Ribeiro, J. F.; Cerrado: Espécies Vegetais Úteis; EMBRAPA: Planaltina, DF, 1998.

8. Silva, G. C.; Braga, F. C.; Lemos, V. S.; Cortes, S. F.; Phytomedicine 2016, 23, 214.

9. Hirschmann, G. S.; Arias, A. R.; J. Ethnopharmacol. 1990, 29 , 159.

10. Pott, A.; Pott, V. J.; Plantas do Pantanal; EMBRAPA: Planaltina, DF, 1994.

11. Mors, W. B.; Rizzini, C. T.; Pereira, N. A.; Medicinal Plants of Brazil (Medicinal Plants of the World); DeFilipps, R. A., ed.; Reference Publications: Michigan, 2000.

12. Pereira, A. C.; Pereira, A. B. D.; Moreira, C. C. L.; Botion, L. M.; Lemos, V. S.; Braga, F. C.; Cortes, S. F.; J. Ethnopharmacol. 2015, 161, 30 .

13. Endringer, D. C.; Pezzuto, J. M.; Braga, F. C.; Phytomedicine 2009, 16, 1064.

14. Neves, J. S.; Franchin, M.; Rosalen, P. L.; Omar, N. F.; dos Santos, M. A.; Paschoal, J. A. R.; Novaes, P. D.; J. Ethnopharmacol. 2016, 183, 151.

15. Gomes, E. B.; Ramalho, S. R.; Gualberto, N. C.; Miranda, R. C. M.; Nigam, N.; Norain, N.; J. Anal. Sci., Methods Instrum. 2013, 3, article ID 37131.

16. Rodrigues, C. M.; Rinaldo, D.; dos Santos, L. C.; Montoro, P.; Piacente, S.; Pizza, C.; Hiruma-Lima, C. A.; Brito, A. R. M. S.; Vilegas, W.; Rapid Commun. Mass Spectrom. 2007, 21, 1907.

17. Alcantara, G. B.; Honda, N. K.; Ferreira, M. M. C.; Ferreira, A. G.; Anal. Chim. Acta 2007, 595, 3.

18. Lião, L. M.; Choze, R.; Cavalcante, P. P. A.; Santos, S. C.; Ferri, P. H.; Ferreira, A. G.; Quim. Nova 2010, 33, 634.

19. Santos, A. D. C.; Fonseca, F. A.; Lião, L. M.; Alcantara, G. B.; Barison, A.; Trends Anal. Chem. 2015, 73, 10.

20. Choze, R.; Alcantara, G. B.; Alves-Filho, E. G.; Silva, L. M. A.; Faria, J. C.; Lião, L. M.; Food Chem. 2013, 141, 2841.

21. Santos, A. D. C.; Fonseca, F. A.; Dutra, L. M.; Santos, M. F. C.; Menezes, L. R. A.; Campos, F. R.; Nagata, N.; Ayub, R.; Barison, A.; Food Chem. 2018, 239, 511.

22. https://octave.en.softonic.com/?ex=DSK-309.0, accessed in August 2017.

23. Boelens, H. F. M.; Eilers, P. H. C.; Hankemeler, T.; Anal. Chem. 2005, 77, 7998.

24. Buszewski, B.; Kawka, S.; Suprynowicz, Z.; Wolski, T.; J. Pharm. Biomed. Anal. 1993, 11, 211.

25. Carvalho, M. G.; Velloso, C. R. X.; Braz-Filho, R.; Costa, W. F.; J. Braz. Chem. Soc. 2001, 12, 556.

Submitted: August 9, 2017 Published online: October 25, 2017 